\title{
METHODOLOGY OF TRAININGS IN THE SCOPE OF HEALTH AND SAFETY
}

doi: $\quad 10.2478 /$ czoto-2019-0032

Date of submission of the article to the Editor: $02 / 11 / 2018$

Date of acceptance of the article by the Editor: 23/12/2018

\author{
Leszek Kieltyka ${ }^{1}$ - orcid id: 0000-0001-7551-491X \\ ${ }^{1}$ Czestochowa University of Technology, Poland, leszek.kieltyka@wz.pcz.pl
}

\begin{abstract}
The paper stresses the importance of trainings in the scope of Health and Safety, in this H\&S management in the functioning H\&S systems of contemporary enterprises. The author also presents the principles of training, including $\mathrm{H} \& \mathrm{~S}$ training, considering: demonstrativeness, accessibility, awareness of social responsibility, regularity, knowledge durability and binary relations between theory and practice.

The underlying objective of the paper is to present training methods in the scope of Health and Safety. These methods have been aggregated in two groups: explanatory methods and activating methods. Referring to the research conducted within the European programme Leonardo da Vinci „H\&S management system in enterprise introductory module" the author has summarised the criteria for selecting teaching methods with regard to: goals and content of training process, diversification of participants in training groups in the scope of H\&S, skills of the trainer and organisational conditions. Moreover, training methods in the scope of $\mathrm{H} \& \mathrm{~S}$ have been aggregated, being highly adjusted and reflecting actual professional activities carried out activities and potential threats that occur at the work post, in the enterprises of training participants. These methods have been characterised considering the following aspects: learning goals, educational resources, organisational conditions and examples of pursued contents.
\end{abstract}

Keywords: Health and safety in enterprises, principles and methods of H\&S training

\section{INTRODUCTION}

Security means a state of mind, therefore security increase, among others, in the working environment is achieved through developing secure attitudes and mental approach (Gładyś and Kwiatkowski, 1997). In this context, it needs to be stressed that $\mathrm{H} \& \mathrm{~S}$ trainings for employees constitute one of the most important factors that ensure security (Podgórski, 2015; Pryor, 2016) at the workplace as well as in the space where professional duties are performed. Thus, the objective of trainings is to prepare employees to performing their tasks, making them acquainted with regulations, first of all the ones related to $\mathrm{H} \& \mathrm{~S}$ in the scope indispensable to perform tasks delegated in the enterprise, at a particular workplace, bearing full responsibility. In the training 
process it is possible to influence learned reactions (repetitiveness of correct employee behaviours), to make some of them habitual ones.

A prolonged, repetitive training in developing knowledge, skills or competences (Paul and Pearse, 2016) in the scope of safety is of key importance in contemporary enterprises. Training in the scope of $\mathrm{H} \& \mathrm{~S}$ should be conducted as: a preliminary training - obligatory for employees prior being allowed to render work - which is divided into a general preliminary training (general training) and preliminary toolbox talks (toolbox tasks) as well as periodic training, updating and establishing the knowledge and skills of employees in the scope of H\&S. Trainings should take place in the working time and the expense of the employer (Kupisiewicz, 1995).

Trainings can be conducted applying various teaching methods. Selection of the method is conditioned by: objectives and contents of the training process. The present paper, with reference to the subject scope defined in its title, concentrates on training methods in the scope of H\&S distinguished within the European programme Leonardo da Vinci „H\&S management system in enterprise - introductory module”, which the author coordinated. The European programme Leonardo da Vinci is a part of a training programme run by the European Union "Lifelong Learning Programme". The main objective of the carried-out programme was to promote activities that increase the quality of training systems and vocational training in the scope of Health and Safety. The Leonardo da Vinci programme especially stressed supporting enterprises and employees in the area of vocational education, cooperation of higher education institutions with production businesses and also improving professional competences (especially young persons - including students), so as to increase their chances on the labour market (Madigan et al., 2019). Project participants included 28 member states of the European Union and Turkey. Developing an international network of institutions that constitute an infrastructure for dissemination of knowledge and experiences at the European level was supposed to gather, improve and also disseminate results of works of international institutions in the scope of designing and implementing the proposed training methods in the area of Health and Safety.

It needs to be stressed that currently, once the international project Leonardo da Vinci „H\&S management system in enterprise - introductory module" has been completed the activities are being continued in the Erasmus+ programme "Education and vocational training".

\section{PRINCIPLES AND METHODS OF TRAININGS IN THE SCOPE OF H\&S}

Training should be conducted in accordance with the principles of teaching. These principles can be defined as elements of standards, complied with by a domain expert, lecturer or teacher - in carried out didactic processes (Rączkowski, 1997; Pagieła and Wolniak, 2013). In the Polish educational literature, the most frequently mentioned teaching principles include (Czekałowicz, 1996; Ejdys, 2010; Koradecka, 1997; Okoń, 1987; Oleszak, 2012): demonstrativeness, accessibility, conscious and active participation in the teaching-learning process as well as regularity, durability of knowledge, developing binary relationships between theory and practice. A synthetic description of these principles has been included in Table 1. The summarised examples are meant to contribute to the rational organisation of the teaching-learning process. They define how teaching objectives are to be carried out. Numerous unusual situations might occur in the didactic work. Thus, teaching requires own initiative and application of common sense. 
Table 1

Portfolio of training principles applied in the scope of H\&S trainings

\begin{tabular}{|c|c|c|}
\hline Training principle & $\begin{array}{c}\text { Short description - nature of } \\
\text { the principle }\end{array}$ & Application tips \\
\hline Demonstrativeness & $\begin{array}{l}\text { It consists in creating in the } \\
\text { teaching-learning process } \\
\text { conditions for the participants } \\
\text { that facilitate remembering and } \\
\text { understanding of definitions, } \\
\text { phenomena, processes, etc. }\end{array}$ & $\begin{array}{l}\text { Application of proper (for teaching } \\
\text { objectives) educational resources. } \\
\text { Professional experience of the } \\
\text { participants needs to be } \\
\text { considered and references should } \\
\text { be made to it (indirect } \\
\text { demonstrativeness }\end{array}$ \\
\hline Accessibility & $\begin{array}{l}\text { Implementing the principle } \\
\text { consists in adjusting the } \\
\text { transfer of knowledge, applied } \\
\text { educational methods and } \\
\text { resources to the abilities of the } \\
\text { course/training/lecture/labora- } \\
\text { tory class participants. }\end{array}$ & $\begin{array}{l}\text { Information about educational } \\
\text { background and professional } \\
\text { experience of the participants need } \\
\text { to be collected and adequately } \\
\text { interpreted. } \\
\text { Introducing new terms and } \\
\text { definitions should be carried out } \\
\text { using language understandable for } \\
\text { the participants. } \\
\text { Contents the participants are } \\
\text { acquainted with should be } \\
\text { introduced first and gradually } \\
\text { progress to new ones. } \\
\text { Participants should not overload } \\
\text { with excess of knowledge. }\end{array}$ \\
\hline $\begin{array}{c}\text { Conscious and } \\
\text { active participation } \\
\text { in the training } \\
\text { process }\end{array}$ & $\begin{array}{l}\text { Implementing the principle } \\
\text { consists in running the classes } \\
\text { in such a manner that the } \\
\text { lecturer is a manager and } \\
\text { organiser of work of the } \\
\text { course/training/lecture/laborato } \\
\text { ry class participants and their } \\
\text { activeness involved inde- } \\
\text { pendent mental effort } \\
\text { (e.g. individual or group work). }\end{array}$ & $\begin{array}{l}\text { This principle can be implemented } \\
\text { on condition that the participants } \\
\text { have been acquainted with } \\
\text { general, indirect and detailed } \\
\text { course objectives. } \\
\text { Participants become active if their } \\
\text { motivation to learn has been } \\
\text { stimulated (motivation depends, } \\
\text { among others, participant's } \\
\text { awareness of the usefulness of } \\
\text { acquired knowledge). } \\
\text { Motivation can be strengthened } \\
\text { through positive stimuli. }\end{array}$ \\
\hline Regularity & $\begin{array}{l}\text { Regularity is one of the } \\
\text { principles that significantly } \\
\text { influence the training process } \\
\text { efficiency. The rules that follow } \\
\text { refer both to the activities of } \\
\text { the lecturer as well as the work } \\
\text { of the course/training/lecture- } \\
\text { /laboratory class participants. }\end{array}$ & $\begin{array}{l}\text { The lecturer should prepare } \\
\text { courses carefully. } \\
\text { The material should be divided into } \\
\text { particular sub-topics and presented } \\
\text { in the correct order. } \\
\text { Main and major issues need to be } \\
\text { stresses and references should be } \\
\text { made to the already acquired } \\
\text { material. } \\
\text { Participants should be made } \\
\text { accustomed to work } \\
\text { independently, give oral or written } \\
\text { answers during each meeting. }\end{array}$ \\
\hline
\end{tabular}




\begin{tabular}{|c|l|l|}
\hline $\begin{array}{c}\text { Knowledge } \\
\text { durability }\end{array}$ & $\begin{array}{l}\text { This principle consists in } \\
\text { applying by the lecturer } \\
\text { educational procedures that } \\
\text { enable the participants to } \\
\text { remember permanently } \\
\text { presented to them information. }\end{array}$ & $\begin{array}{l}\text { Knowledge is well established } \\
\text { when the lecturer organises the } \\
\text { educational process so as to } \\
\text { ensure active involvement of the } \\
\text { participants. } \\
\text { Having ensured that the } \\
\text { participants understood the } \\
\text { presented contents well, revision } \\
\text { exercises should be applied. } \\
\text { Reviews of the material should be } \\
\text { conducted. } \\
\text { Systematic control of teaching } \\
\text { outcomes needs to be applied. }\end{array}$ \\
Combining theory \\
and practice
\end{tabular}

Source: Czekałowicz, 1994; Czekałowicz, 1996, Ejdys, 2010; Gembalska-Kwiecień and Żurakowski, 2015; Koradecka, 1997; Okoń, 1987; Oleszak, 2012; Rączkowski, 1997; Pagieła and Wolniak, 2013

Trainings in the scope of H\&S can be conducted with the use of various teaching methods. A teaching method is a consciously conducted and regularly repeated manner of work of the lecturer and the course participants that determines that the assumed objectives of training have been achieved (Freitas and Silva, 2017; Pagieła and Wolniak, 2013; Strykowski, 1984).

Appropriate selection of the teaching method is conditioned by:

objectives and content of the training process,

composition and educational background of the participants,

skills of the lecturer,

organisational conditions.

Out of numerous division criteria of the methods, the most frequently applied one is the criterion of stimulating and maintaining participants' activeness, according to which the methods can be divided into:

1. Explanatory ones, i.e. where the source of the information is an expert, lecturer, teacher. They ensure activeness primarily of one side, i.e. the person providing the content while the participants are merely receivers of the passed information.

2. Activating ones, i.e. the ones that in the teaching-learning process create the conditions for the participants to take an active part in the training. Man learns best through own actions. The lecturer takes the position of the person managing the process of problem solving. The acquired knowledge and skill are permanent and can be easily adopted in other domains of man's activity.

The explanatory methods include: information lecture, story, anecdote, description, explanation, demonstration, instruction.

The activating methods most frequently applied in trainings for adults include: demonstration of activities, oral and demonstration instruction, problem lecture, conversation lecture, discussion method (panel, multiple), brainstorming, moderation method, situational method, case study method, talk, project method, staging method and laboratory method. 
The abovementioned methods: explanatory and activating ones were implemented in the pilot trainings in the scope of H\&S within the Leonardo da Vinci programme. The established knowledge of the participants was verified (Robson et al., 2012), after each of the courses had been completed. As a result, the control and evaluation of the teaching outputs constituted a basis for selecting the most efficient methods (highest evaluation marks), such as: lecture method, discussion method, situational method and laboratory method. Synthetic characteristics of these methods, considering: educational objectives, educational materials, organisational conditions and examples of pursued contents have been summarised in Table 2.

Table 2

Distinguished methods in the process of knowledge acquisition of H\&S trainings participants

\begin{tabular}{|c|c|c|c|c|}
\hline $\begin{array}{l}\text { Method's } \\
\text { name }\end{array}$ & $\begin{array}{c}\text { Educational } \\
\text { objectives it } \\
\text { pursues }\end{array}$ & $\begin{array}{l}\text { Educational } \\
\text { resources }\end{array}$ & $\begin{array}{l}\text { Organisational } \\
\text { conditions }\end{array}$ & $\begin{array}{l}\text { Examples of } \\
\text { pursued } \\
\text { contents, } \\
\text { remarks }\end{array}$ \\
\hline 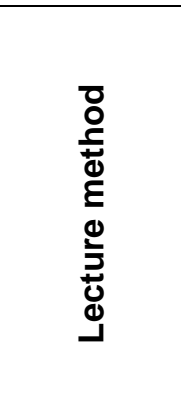 & $\begin{array}{l}\text { Becoming } \\
\text { acquainted with } \\
\text { new information. } \\
\text { Knowledge } \\
\text { update. }\end{array}$ & $\begin{array}{l}\text { Outline, } \\
\text { educational } \\
\text { resources (e.g. } \\
\text { multimedia } \\
\text { presentations, } \\
\text { training videos, } \\
\text { webinars, online } \\
\text { training } \\
\text { platforms). }\end{array}$ & $\begin{array}{l}\text { Lecture rooms } \\
\text { adapted to the } \\
\text { needs } \\
\text { multimedia } \\
\text { presentations } \\
\text { having Internet } \\
\text { access. }\end{array}$ & $\begin{array}{l}\text { Passing a large } \\
\text { amount of new } \\
\text { information to the } \\
\text { participants. } \\
\text { Lecture duration } \\
\text { time should be } \\
\text { limited to } \\
\text { indispensable } \\
\text { minimum. }\end{array}$ \\
\hline 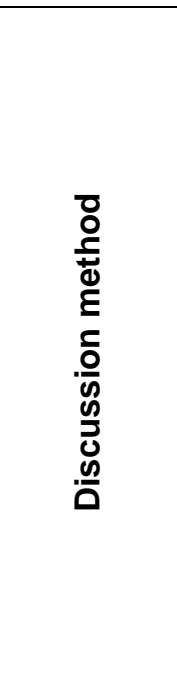 & $\begin{array}{l}\text { Teaching effective } \\
\text { communication. } \\
\text { Improving the } \\
\text { ability to analyse } \\
\text { and solve } \\
\text { problems. } \\
\text { Developing an } \\
\text { approach of being } \\
\text { tolerant towards } \\
\text { different views. }\end{array}$ & $\begin{array}{l}\text { Prepared topics, } \\
\text { problems for } \\
\text { discussion, } \\
\text { presented in } \\
\text { verbal form or } \\
\text { as multimedia } \\
\text { presentations. }\end{array}$ & $\begin{array}{l}\text { Access to several } \\
\text { rooms adapted to } \\
\text { group work, with } \\
\text { Internet access } \\
\text { and multimedia } \\
\text { equipment }\end{array}$ & $\begin{array}{l}\text { Making } \\
\text { participants } \\
\text { acquainted with } \\
\text { particularly } \\
\text { difficult and } \\
\text { complex } \\
\text { principles. } \\
\text { Confronting } \\
\text { various opinions } \\
\text { so as to obtain } \\
\text { potential } \\
\text { solutions. } \\
\text { Preparation to } \\
\text { group problem } \\
\text { solving. }\end{array}$ \\
\hline 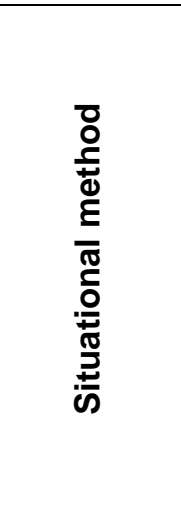 & $\begin{array}{l}\text { Developing } \\
\text { organisational } \\
\text { skills. } \\
\text { Developing the } \\
\text { ability to notice } \\
\text { and analyse } \\
\text { problems. } \\
\text { Developing the } \\
\text { ability to make } \\
\text { decisions. }\end{array}$ & $\begin{array}{l}\text { Description of a } \\
\text { situation (e.g. a } \\
\text { training } \\
\text { situational video } \\
\text { or a description } \\
\text { of a situation for } \\
\text { each participant } \\
\text { presented in } \\
\text { verbal form and } \\
\text { as multimedia } \\
\text { presentations. }\end{array}$ & $\begin{array}{l}\text { Large lecture room } \\
\text { for plenary } \\
\text { meetings or rooms } \\
\text { for groups. } \\
\text { Paper sheets for } \\
\text { groups or group } \\
\text { access to made } \\
\text { available in the } \\
\text { cloud applications } \\
\text { (e.g. text, graphic, } \\
\text { spreadsheets) }\end{array}$ & 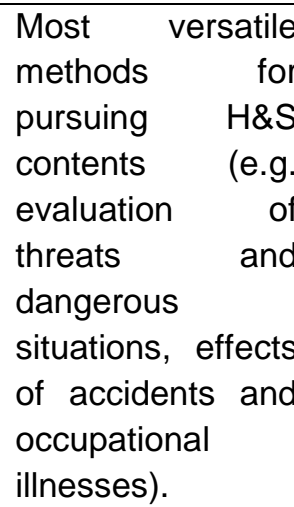 \\
\hline
\end{tabular}




\begin{tabular}{|c|c|c|c|c|}
\hline 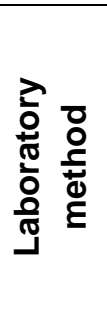 & $\begin{array}{l}\text { Education and } \\
\text { development, } \\
\text { establishing } \\
\text { acquired skills. }\end{array}$ & $\begin{array}{l}\text { Written } \\
\text { materials, e.g. } \\
\text { tables, forms. } \\
\text { Description of } \\
\text { the task. } \\
\text { Simulation } \\
\text { games }\end{array}$ & $\begin{array}{l}\text { Lecture rooms } \\
\text { adapted to } \\
\text { multimedia } \\
\text { presentations and } \\
\text { having Internet } \\
\text { access }\end{array}$ & $\begin{array}{l}\text { Acquiring skills of } \\
\text { keeping records } \\
\text { related to health } \\
\text { and safety. }\end{array}$ \\
\hline
\end{tabular}

Source: (Kiełtyka, 2000)

It should be stressed here that in order to improve the learning process it is vital to properly select educational resources (Tremblay and Badri, 2018), which have also been assigned in Table 2 to the distinguished training methods in the scope of health and safety. Educational resources can be divided into the following ones:

$>$ visual,

$>$ audio,

$>$ audio-visual,

$>$ automating teaching-learning process, e.g. using online training platforms, social media simulation games or e-learning tools.

In practice educational resources are frequently applied in so called multimedia sets.

On the basis of the research conducted within the carried-out Leonardo da Vinci project it can be concluded that trainings in the scope of H\&S using multimedia support, among others, using online training platforms, social media simulation games but also e-learning tools, ensure:

$>28 \%$ time saving,

growth in effectiveness by $43 \%$,

$>$ autonomous, interactive multimedia materials can be used individually (flexibility, repetitiveness) as well as during group work.

\section{DISCUSSION}

Given the implementation and application of training methods in the scope of Health and Safety one should consider that these methods and trainings can be unified with other areas of training. As it has already been emphasised Health and Safety is one of the most important areas that ensures safety at the workplace as well as in the scope of performing professional duties (Gopang et al., 2015). Knowledge, skills or social competences acquired during H\&S trainings should be clearly adjusted and reflect practical professional actions in the context of carried out tasks and potential threats that occur at the workplace, but also in the entire enterprise. The distinguished in the paper methods, such as: lecture method, discussion method, situational method and laboratory method ensure such adjustment. They can be applied in groups of discussed trainings participants that are diversified with regard to: ethnic origin, culture, educational background, but which is also of key importance for enterprises in mixed- age groups. In this context is vital to possess the ability to select topic for classes, time and place of the training, activate discussion participants. e.g. in the scope of identifying, reducing or eliminating threats at heterogeneous workplaces. It is also crucial to verify the acquired knowledge, skills, social competences, not only in the form of exams or tests, as it has been the case in the previous practice of H\&S trainings, but also in the simulated working conditions with the use of situational 
games or ever more frequently utilised virtual reality to simulate threats to health or life of the course participants at heterogeneous workplaces.

Persons participating in these trainings, in the simulated environment that reflects actual threats, usually have to solve two problems: explain the origins of the phenomenon observed and visualised with the use of multimedia tools or analyse the possibility to prevent or change a given situation. Moreover, this can constitute a basis to analyse the training efficiency, quality of conducting classes, manner of sharing the information, assessment of heterogeneous training materials (including multimedia or interactive ones) and a possibility to apply in practice the acquired knowledge, skills, social competences in the scope of Health and Safety.

\section{CONCLUSION}

All in all, a success of a training in the scope of Health and Safety is conditioned by numerous factors, including the methods as well as conditions in which it has been conducted. Observations of the pilot groups that have been trained within the Leonardo da Vinci project show unambiguously that positive effects - acquisition of knowledge, skills, social competences of safe work, cannot be produced if they are provided in the conditions that indicate that both persons conducting the training as well as its participants do not treat it seriously. Therefore, periodic training that are still practised, which often takes place during lunch breaks or similar situations, needs to be promptly replaced with e.g. training courses organised in the conditions that suggest a high rank of this process. Additionally, the research conducted within the carried-out project confirms unequivocally that despite an extensive portfolio of explanatory and activating methods in the scope of H\&S training should be clearly adjusted and reflect practical professional activities in the context of performed tasks and potential threats that occur at the workplace. They should also be adjusted to the participants differentiated with regard to ethnic origin, culture, educational background or age.

\section{REFERENCES}

Czekałowicz, S., 1994. Jak uczyć BHP na stanowisku pracy. Proergo, Warszawa.

Czekałowicz, S., 1996. Szkolenie okresowe BHP w zakładzie pracy. Proergo, Warszawa.

Ejdys, J. (red.), 2010. Kształtowanie kultury bezpieczeństwa $i$ higieny pracy w organizacji. Oficyna Wydawnicza Politechniki Białostockiej, Białystok.

Freitas, A.C., Silva, S.A., 2017. Exploring OHS trainers' role in the transfer of training. Safety Science, 91, 310-319, DOI: 10.1016/j.ssci.2016.08.007

Gembalska-Kwiecień, A., Żurakowski, Z., 2015. Potrzeba szkoleń z zakresu bezpieczeństwa $i$ higieny pracy $w$ przedsiębiorstwie $w$ ocenie pracowników. Zeszyty Naukowe Politechniki Śląskiej, Seria: Organizacja i Zarządzanie, z. 77, nr kol. 1927, 85-91.

Gładyś, J., Kwiatkowski, S., 1997. Bezpieczeństwo i ochrona człowieka w środowisku pracy, modut 18 Organizacja i metodyka szkolenia oraz popularyzacja bezpieczeństwa pracy. CIOP, Warszawa.

Gopang, M.A., Nebhwani, M., Khatri, A., Marri, H.B., 2015. An assessment of occupational health and safety measures and performance of SMEs: An empirical investigation. Safety Science, 93, 127-133, DOI: 10.1016/j.ssci.2016.11.024 
Kiełtyka, L., 2000. System zarządzania bezpieczeństwem i higieną pracy w przedsiębiorstwie - Moduł wdrożeniowy. Wydawnictwo Politechniki Częstochowskiej, Częstochowa.

Koradecka, D., 1997. Bezpieczeństwo pracy i ergonomia. CIOP, Warszawa.

Kupisiewicz, C., 1995. Podstawy dydaktyki ogólnej. Polska Oficyna Wydawnicza "BGW", Warszawa.

Madigan, C., Johnstone, K., Cook, M., Brandon, J., 2019. Do student internships build capability? - What OHS graduates really think. Safety Science, 111, 102-110, DOI: 10.1016/j.ssci.2018.10.003

Okoń, W., 1987. Słownik pedagogiczny, wyd. 4, PWN, Warszawa.

Oleszak, A., 2012. Problemy dydaktyczne szkoleń z zakresu bezpieczeństwa i higieny pracy. Edukacja humanistyczna, nr 1 (26), 191-199, Szczecin.

Pagieła, J., Wolniak, R., 2013. Nowa jakość szkoleń w dziedzinie bezpieczeństwa $i$ higieny pracy. Zeszyty Naukowe Politechniki Śląskiej, Seria: Organizacja i Zarządzanie, z. 67, nr kol. 1900, 75-86.

Paul, G., Pearse, W., 2016. An international benchmark for the Australian OHS Body of Knowledge (BoK). Safety Science, 81, 13-24, DOI: 10.1016/j.ssci.2015.07.016

Podgórski, D., 2015. Measuring operational performance of OSH management system - A demonstration of AHP-based selection of leading key performance indicators. Safety Science, 73, 146-166, DOI: 10.1016/j.ssci.2014.11.018

Pryor, P., 2016. Accredited OHS professional education: A step change for OHS capability. Safety Science, 81, 5-12, DOI: 10.1016/j.ssci.2015.04.005

Rączkowski, B., 1997. BHP w praktyce. ODDK, Gdańsk.

Robson, L.S., Macdonald, S., Gray, G.C., Van Eerd, D.L, Bigelow, P.L., 2012. A descriptive study of the OHS management auditing methods used by public sector organizations conducting audits of workplaces: Implications for audit reliability and validity. Safety Science, 50/2, 181-189, DOI: 110.1016/j.ssci.2011.08.006

Strykowski, W., 1984. Audiowizualne materiały dydaktyczne: podstawy kształcenia multimedialnego. PWN, Warszawa.

Tremblay, A., Badri, A., 2018, Assessment of occupational health and safety performance evaluation tools: State of the art and challenges for small and medium-sized enterprises. Safety Science, 101, 260-267.

DOI: 10.1016/j.ssci.2017.09.016 